\title{
Exploring Relationships among Social Norms, Aesthetics, HOA Regulations and Water Conservation ${ }^{1}$
}

\author{
Amanda D. Ali and Laura A. Sanagorski Warner ${ }^{2}$
}

\section{Abstract}

In the United States, landscape irrigation often comprises $50 \%$ or more of residential water used by a household (Hurd, 2006), and aesthetics may take preference over water-conserving elements in the landscape. Other factors such as perceived social norms and homeowners' association (HOA) regulations also impact water conservation behaviors (Wentz, Rhode, Li, Tellman, \& Turner, 2016; Zmyslony \& Gagnon, 1998). Binary logistic regression was used to estimate the impact of aesthetics, perceived social norms, and HOA regulations on water conservation intentions. Findings revealed that when individuals placed a higher-than-average value on aesthetics and perceived stronger social support for conservation, home irrigation users had greater intent to conserve water.

\section{Introduction}

Improved irrigation management can reduce landscape water usage between $35 \%$ and $70 \%$ in residential areas (Hurd, 2006). There is an opportunity to encourage changes in landscape preferences and homeowner choices by promoting water conservation behaviors (Hayden, Cadenasso, Haver \& Oki, 2015). Universally appealing landscapes are those displaying groomed lawns and orderly plantings (Nassauer, 1988; Nassauer et al., 2009). The appearance of a landscape plays an important role in water consumption (Hayden et al., 2015). Nielson and Smith (2005) noted the presence of HOAs and strong preferences for specific landscape aesthetics influenced landscape maintenance choices, leading to overirrigation of lawns. In the study by Hayden et al. (2015), residents valued aesthetics more than the amount of water required for maintenance.

Landscape aesthetics can be associated with social norms. According to Zmyslony and Gagnon (1998), residents considered the appearance of their neighbors' landscapes when making decisions about their own. They engaged in social contagion or neighbor mimicry by replicating the aesthetic appeal of their neighbors' landscape. Thus, social norms play an important role in encouraging water conservation behaviors. Boards and legal institutions such as HOAs also monitor and regulate the appearance and management of landscapes in many residential areas (Martin, Peterson, \& Stabler, 2003), which can lead to overirrigation (Nielson \& Smith, 2005). Wentz et al.s (2016) contrasting findings led the researchers to assert that the HOA regulations, covenants, and water restrictions can reduce outdoor water usage by roughly $24 \%$ during peak seasons. These contradictory findings reveal that $\mathrm{HOA}$ regulations can positively or negatively influence water conservation behaviors. The study summarized in this publication sought to estimate the effect of landscape aesthetics, perceived social norms, and HOA regulations on residents' intent to conserve water. Understanding factors affecting water use in residential areas can help inform effective water conservation campaigns.

1. This document is AEC668, one of a series of the Department of Agricultural Education and Communication, UF/IFAS Extension. Original publication date April 2019. Visit the EDIS website at https://edis.ifas.ufl.edu for the currently supported version of this publication.

2. Amanda D. Ali, graduate student; and Laura A. Sanagorski Warner, assistant professor, Department of Agricultural Education and Communication; UF/ IFAS Extension, Gainesville, FL 32611.

The Institute of Food and Agricultural Sciences (IFAS) is an Equal Opportunity Institution authorized to provide research, educational information and other services only to individuals and institutions that function with non-discrimination with respect to race, creed, color, religion, age, disability, sex, sexual orientation, marital status, national origin, political opinions or affiliations. For more information on obtaining other UF/IFAS Extension publications, contact your county's UF/IFAS Extension office. 


\section{Exploring Factors Affecting Water Conservation}

The Theory of Planned Behavior (TPB; Ajzen, 1991) guided this study. The TPB comprises three variables (attitude toward a behavior, subjective norms surrounding a behavior, and perceived behavioral control over a behavior). It states that when all three variables are positive, the intent of a person to engage in a behavior is high, which eventually leads to the adoption of the behavior (Ajzen, 1988). In this study, intent to engage in landscape water conservation practices was the outcome variable. Of the three TPB variables, this study focused on subjective norms (or perceived social norms), which are the perceived social pressures to engage or not engage in a behavior. Subjective norms were the focus because they are considered a powerful predictor of motivation (Schultz, 1998). The assumption was when perceived social norms to engage in landscape water conservation practices were high, the intent to engage in water conservation would also be high.

We surveyed 644 residential members of HOAs who had irrigated landscapes in the United States. To determine the general structure of the HOA, we asked respondents to indicate if their HOA had any policies or requirements related to landscaping, recognized or rewarded residents for the look of their landscapes, or imposed penalties for the appearance of landscapes. The responses for each of these three questions were yes, no, or I don't know.

Descriptive statistics provided information on the value residents placed on landscape aesthetics and perceived social norms. More than half of respondents were female $(52 \% ; n=335)$, and the average respondent averaged 40 years of age, possessed a 4-year degree, and earned $\$ 50,000$ to $\$ 74,999$ annually. A 5-point Likert-type scale with three statements and responses ranging from strongly disagree to strongly agree was used to measure respondents' value of landscape aesthetics (Table 1). Participants agreed they valued their landscape because it was aesthetically pleasing, and $50 \%$ placed a higher-than-average value on their landscape aesthetics.

A 5-point Likert-type scale ranging from strongly disagree to strongly agree for each of five statements was used to measure perceived social norms to engage in water conservation (Table 2). Most respondents perceived strong social norms surrounding water conservation, and $49.1 \%$ reported higher-than-average perceived social norms.
Table 1. Descriptive results for landscape aesthetics in a study estimating the impact of aesthetics, perceived social norms, and HOA regulations on residents' intent to conserve water.

\begin{tabular}{|l|c|c|c|c|c|}
\hline $\begin{array}{l}\text { I value my home landscape } \\
\text { because it: }\end{array}$ & SD & D & N & A & SA \\
\hline & \multicolumn{5}{|c|}{$\%$} \\
\hline Is enjoyable to look at & 0.5 & 0.7 & 4.4 & 47.0 & 47.4 \\
\hline Is aesthetically pleasing & 0.5 & 0.5 & 5.7 & 47.8 & 45.4 \\
\hline $\begin{array}{l}\text { Screens unwanted views } \\
\text { Percent placing higher-than- } \\
\text { average value on landscape } \\
\text { aesthetics } \\
\text { (* } 1 \text { if high, 0 other) }\end{array}$ & 50.0 & 7.2 & 15.8 & 45.3 & 30.4 \\
\hline $\begin{array}{l}\text { Note. SD—Strongly Disagree, D—Disagree, N-Neither agree nor } \\
\text { disagree, A-Agree, SA-Strongly Agree. } \\
\text { *Mean-centered indicator for landscape aesthetics }\end{array}$ & & & & \\
\hline
\end{tabular}

Table 2. Descriptive results for importance of perceived social norms in a study estimating the impact of aesthetics, perceived social norms, and HOA regulations on residents' intent to conserve water.

\begin{tabular}{|l|c|c|c|c|c|}
\hline Perceived social norms statements & SD & D & N & A & SA \\
\hline $\begin{array}{l}\text { The people who are important } \\
\text { to me would approve if I reduced } \\
\text { my landscape impact on water } \\
\text { resources }\end{array}$ & 1.6 & 3.0 & 15.4 & 48.3 & 31.8 \\
\hline $\begin{array}{l}\text { The people who are important to } \\
\text { me would approve if I explored } \\
\text { ways to reduce my impact on } \\
\text { water resources }\end{array}$ & 1.2 & 2.5 & 14.6 & 53.4 & 28.3 \\
\hline $\begin{array}{l}\text { The people who are important } \\
\text { to me expect that I will manage } \\
\text { my landscape using the smallest } \\
\text { amount of water possible }\end{array}$ & 2.0 & 7.0 & 27.0 & 41.0 & 22.7 \\
\hline $\begin{array}{l}\text { The people who are important to } \\
\text { me expect that I will minimize my } \\
\text { personal impact on local water } \\
\text { resources }\end{array}$ & 2.2 & 8.9 & 32.0 & 36.3 & 20.7 \\
\hline $\begin{array}{l}\text { The people who are important } \\
\text { to me think I should encourage } \\
\text { others to protect our water } \\
\text { resources }\end{array}$ & 2.8 & 8.9 & 31.1 & 37.7 & 19.6 \\
\hline $\begin{array}{l}\text { Percent stating higher-than- } \\
\text { average influence of social norms } \\
\text { (*S = 1 if high, 0 other) }\end{array}$ & 49.1 & & & & \\
\hline $\begin{array}{l}\text { Note: SD-Strongly Disagree, D-Disagree, N-Neither agree nor } \\
\text { disagree, A-Agree, SA-Strongly Agree } \\
\text { *Mean-centered indicator of perceived social norms }\end{array}$ & & & & & \\
\hline & & & & & \\
\hline
\end{tabular}




\section{Understanding the Impact of Aesthetics, Social Norms, and HOA Regulations on Water Conservation}

Intent to engage in landscape water conservation practices was measured by presenting ten specific water conservation practices along a Likert-type scale. Respondents were asked to indicate their likelihood of adopting each of the practices on a 5-point scale ranging from very unlikely to very likely. We calculated the mean of these responses and used it as the outcome variable in the following analyses.

Binary logistic regression was used to estimate the likelihood of engagement in water conservation practices based on value of landscape aesthetics, perceived social norms, and presence of HOA regulations. Both value of landscape aesthetics and perceived social norms had a statistically significant effect on intent to conserve water. However, HOA regulation had no statistically significant impact on intent to conserve water. Results showed when residents' value of landscape aesthetics was higher than average, $62.0 \%$ of respondents had intent to conserve water (Figure 1). Results also showed when perceived social norms were higher than average, $79.9 \%$ of respondents intended to conserve water.

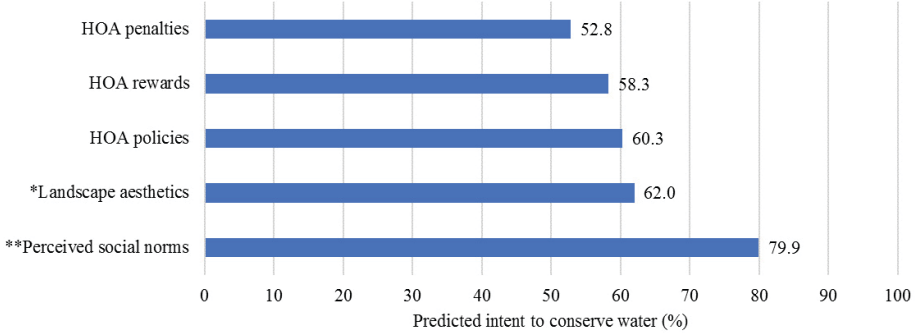

Figure 1. Predicted percentages of intent to conserve water. ${ }^{* *} \mathrm{p}<$ $0.001 ;{ }^{*} p<0.01$

Half of the respondents placed higher-than-average values on landscape aesthetics. This result is consistent with findings reported by Hayden et al. (2015). Furthermore, roughly half (49.1\%) of respondents perceived stronger social norms surrounding water conservation, consistent with findings by Nassauer et al. (2009) and Zmyslony and Gagnon (1998).

\section{How to Use This Information}

Since the greatest intent to conserve water was based on perceived social norms, natural resources communication professionals can:
- Collaborate with community members in water conservation campaigns. One strategy to engage community members would be to encourage dialogues with $\mathrm{HOA}$ residents already involved with water conservation practices. Community-wide conservation talks could be implemented to raise awareness of landscape water conservation and develop a water-conservation norm throughout an HOA.

- Develop social norm messages. Appealing to the desire of water-conservation social norms can stimulate engagement in water-saving behaviors. Natural resources communication professionals could develop campaigns promoting attractive landscapes with reduced water usage.

For more information about using social norms as a behavior change strategy, visit Using Social Norms to Increase Behavior Change in Sustainable Landscaping (http://edis. ifas.ufl.edu/wc158).

\section{Conclusion}

From the literature, we expected higher values placed on landscape aesthetics would lead to a decrease in intent to conserve water because residents may be likely to overirrigate. However, our results indicated respondents intended to conserve water while placing high values on landscape aesthetics at the same time. This result was inconsistent with findings by Hayden et al. (2015). A potential explanation can be neighbor mimicry or interactions with neighbors as described by Zmyslony and Gagnon (1998). Residents inclined to mimic their neighbors' actions may also consider their water-saving practices. Future research should test the efficacy of messages appealing to social norms promoting the compatibility of landscape aesthetics and evaluate other methods for integrating social norms into outreach programs.

\section{Acknowledgments}

The University of Florida Institute of Food and Agricultural Sciences Early Career Scientist Seed Fund program supported this research.

\section{References}

Ajzen, I. (1988). Attitudes, personality, and behavior. Milton Keynes, UK: Open University Press.

Hayden, L., Cadenasso, M. L., Haver D., \& Oki, L. R. (2015). Residential landscape aesthetics and water conservation best management practices: Homeowner perceptions and 
preferences. Landscape and Urban Planning, 144, 1-9.

doi:10.1016/j.landurbplan.2015.08.003

Hurd, B. H. (2006). Water conservation and residential landscapes: Household preferences, household choices. Journal of Agricultural and Resource Economics, 31(2), 173-192. Retrieved from http://aggie-horticulture.tamu. edu/faculty/hall/EllisonChair/Water/Water\%20conservation\%20and\%20residential\%20landscapes.pdf

Martin, C. A., Peterson, K. A., \& Stabler, L. B. (2003). Residential landscaping in Phoenix, Arizona, U.S.: Practices and preferences relative to covenants, codes, and restrictions. Journal of Arboriculture, 29(1), 9-17. doi: $10.1145 / 782941.782945$

Nassauer, J. (1988). The aesthetics of horticulture: Neatness as a form of care. HortScience, 23(6), 973-977. Retrieved from https://deepblue.lib.umich.edu/handle/2027.42/49345

Nassauer, J., Wang, Z., \& Deyrell, E. (2009). What will the neighbors think? Cultural norms and ecological design. Landscape and Urban Planning, 92(3-4), 282-292. doi:10.1016/j.landurbplan.2009.05.010

Nielson, L., \& Smith, C. L. (2005). Influences on residential yard care and water quality: Tualatin watershed, Oregon. Journal of the American Water Resources Association, 41(1), 93-106. doi:10.1111/j.1752-1688.2005.tb03720.x

Schultz, P. W. (1998). Changing behavior with normative feedback interventions: A field experiment on curbside recycling. Basic and Applied Psychology 21(1), 25-36. doi:10.1207/s15324834basp2101_3

Wentz, E. A., Rhode, S., Li, X., Tellman, E. M., \& Turner II, B, L. (2016). Impact of homeowner association (HOA) landscaping guidelines on residential water use. Water Resources Research, 52, 3373-3386.

doi:10.1002/2015WR018238

Zmyslony, J., \& Gagnon, D. (1998). Residential management of urban front-yard landscape: A random process? Landscape and Urban Planning, 40(4), 295-307. Retrieved from http://www.sciencedirect.com/science/ journal/01692046/40 